University at Buffalo School of Law

Digital Commons @ University at Buffalo School of Law

1984

\title{
The Oven Bird's Song: Insiders, Outsiders, and Personal Injuries in an American Community
}

David M. Engel

University at Buffalo School of Law

Follow this and additional works at: https://digitalcommons.law.buffalo.edu/journal_articles

Part of the Law and Society Commons, and the Torts Commons

\section{Recommended Citation}

David M. Engel, The Oven Bird's Song: Insiders, Outsiders, and Personal Injuries in an American Community, 18 Law \& Soc'y Rev. 551 (1984).

Available at: https://digitalcommons.law.buffalo.edu/journal_articles/489

(C) 1984 Law and Society Association

\section{IN COPYRIGHT}

This Article is brought to you for free and open access by the Faculty Scholarship at Digital Commons @ University at Buffalo School of Law. It has been accepted for inclusion in Journal Articles by an authorized administrator of Digital Commons @ University at Buffalo School of Law. For more information, please contact lawscholar@buffalo.edu. 


\title{
THE OVEN BIRD'S SONG: INSIDERS, OUTSIDERS, AND PERSONAL INJURIES IN AN AMERICAN COMMUNITY*
}

\author{
DAVID M. ENGEL**
}

\begin{abstract}
In "Sander County" Illinois, concerns about litigiousness in the local population tended to focus on personal injury suits, although such cases were very rarely brought. This article explores the roots of these concerns in the ideology of the rural community and in the reactions of many residents to social, cultural, and economic changes that created a pervasive sense of social disintegration and loss. Personal injury claims are contrasted with contract actions, which were far more numerous yet were generally viewed with approval and did not give rise to perceptions of litigiousness or greed. The distinction is explained in terms of changing conceptions of the community itself and in terms of the problematic relationships between "insiders" and "outsiders" in Sander County.
\end{abstract}

\section{INTRODUCTION}

Although it is generally acknowledged that law is a vital part of culture and of the social order, there are times when

* The title refers to Robert Frost's poem "The Oven Bird," which describes a response to the perception of disintegration and decay not unlike the response that is the subject of this paper:

There is a singer everyone has heard,

Loud, a mid-summer and a mid-wood bird,

Who makes the solid tree trunks sound again.

He says that leaves are old and that for flowers

Mid-summer is to spring as one to ten.

He says the early petal-fall is past

When pear and cherry bloom went down in showers

On sunny days a moment overcast;

And comes that other fall we name the fall.

He says the highway dust is over all.

The bird would cease and be as other birds

But that he knows in singing not to sing.

The question that he frames in all but words

Is what to make of a diminished thing.

From The Poetry of Robert Frost, edited by Edward Connery Lathem. Copyright 1916, (C) 1969 by Holt, Rinehart and Winston. Copyright 1944 by Robert Frost. Reprinted by permission of Holt, Rinehart and Winston, Publishers.

** I am deeply grateful to the residents of "Sander County" for their generous participation in this study. I would also like to thank the following 
the invocation of formal law is viewed as an anti-social act and as a contravention of established cultural norms. Criticism of what is seen as an overuse of law and legal institutions often reveals less about the quantity of litigation at any given time than about the interests being asserted or protected through litigation and the kinds of individuals or groups involved in cases that the courts are asked to resolve. Periodic concerns over litigation as a "problem" in particular societies or historical eras can thus draw our attention to important underlying conflicts in cultural values and changes or tensions in the structure of social relationships.

In our own society at present, perhaps no category of litigation has produced greater public criticism than personal injuries. The popular culture is full of tales of feigned or exaggerated physical harms, of spurious whiplash suits, ambulance-chasing lawyers, and exorbitant claims for compensation. Scholars, journalists, and legal professionals, voicing concern with crowded dockets and rising insurance costs, have often shared the perception that personal injury litigation is a field dominated by overly litigious plaintiffs and by trigger-happy attorneys interested only in their fee (Seymour, 1973: 177; Tondel, 1976: 547; Perham, 1977; Rosenberg, 1977: 154; Taylor, 1981; Gest et al., 1982; Greene, 1983).

To the mind agitated by such concerns, Sander County (a pseudonym) appears to offer a quiet refuge. In this small, predominantly rural county in Illinois, personal injury litigation rates were low in comparison to other major categories of litigation ${ }^{1}$ and were apparently somewhat lower

friends and colleagues who read and commented on this article at one stage or another in its development: Richard L. Abel, James B. Atleson, Guyora Binder, Donald Black, Marc Galanter, Fred Konefsky, Virginia Leary, Richard O. Lempert, Felice J. Levine, John Henry Schlegel, Eric H. Steele, Robert J. Steinfeld, and Barbara Yngvesson. I am also grateful to Linda Kosinski for her skill and patience in typing and retyping the manuscript.

The research on which this article is based was supported by the National Science Foundation under Grant No. SOC 77-11654 and by the American Bar Foundation. Opinions, findings, and conclusions are those of the author and not of the supporting organizations.

1 By "litigation" I mean simply the filing of a formal complaint in the civil trial court, even if no further adversarial processes occur. The annual litigation rate for personal injuries was 1.45 cases filed per 1,000 population as compared to 13.7 contract cases (mostly collection matters), 3.62 propertyrelated cases (mostly landlord-tenant matters), and $\mathbf{1 1 . 7 4}$ family-related cases (mostly divorces). All litigation rates are based on the combined civil filings for 1975 and 1976 in the Sander County Court. Population figures are based on the 1970 census and are therefore somewhat understated. That is, the actual litigation rates for 1975-1976 are probably lower than those given here. 
than the personal injury rates in other locations as well. ${ }^{2}$ Yet Sander County residents displayed a deep concern with and an aversion toward this particular form of "litigious behavior" despite its rarity in their community. ${ }^{3}$

Those who sought to enforce personal injury claims in Sander County were characterized by their fellow residents as "very greedy," as "quick to sue," as "people looking for the easy buck," and as those who just "naturally sue and try to get something [for] ... life's little accidents." One minister describing the local scene told me, "Everybody's going to court. That's the thing to do, because a lot of people see a chance to make money." A social worker, speaking of local perceptions of personal injury litigation, particularly among the older residents of Sander County, observed: "Someone sues every time you turn around. Sue happy, you hear them say. Sue happy." Personal injury plaintiffs were viewed in Sander County as people who made waves and as troublemakers. Even members of the community who occupied positions of prestige or respect could not escape criticism if they brought personal

2 McIntosh reports a rate of approximately 6 tort actions per 1,000 population in the St. Louis Circuit Court in 1970. He does not state what proportion of these involved personal injuries (McIntosh, 1980-81: 832). Friedman and Percival (1976: 281-82) report 2.80 and 1.87 cases filed per 1,000 population in the Alameda and San Benito Superior Courts (respectively) in 1970 under the combined categories of "auto accidents" and "other personal injuries." The two California courts had original jurisdiction only for claims of $\$ 5,000$ or more, however, while the Sander County figures include personal injury claims of all amounts. Friedman and Percival do not indicate what proportion of the auto accident cases involved personal injuries as opposed to property damage only. Statewide data for California and New York, compiled by the National Center for State Courts $(1979$ : 49,51) for tort cases filed in 1975 , also tend to indicate litigation rates higher than Sander County's. However, these aggregate litigation rates are understated in that they exclude filings from smaller courts of limited jurisdiction in both states and are overstated in that they fail to separate personal injury cases from other tort actions. Litigation rates for tort cases filed per 1,000 population in 1975 are: California, 3.55; and New York, 2.21 (but in 1977, when additional lower court dockets were included in the survey of tort cases filed, the rate reported for New York more than doubled to 4.47; see National Center for State Courts, 1982: 61). In comparing the Sander County litigation rates to those in other cities or states, it should also be remembered that, because Sander County was quite small, the absolute number of personal injury actions filed in the county court was also very small compared to more urban areas.

3 I use the term "community" somewhat loosely in this discussion to mean the county seat of Sander County and the surrounding farmlands. Since Sander County is rather small, this takes in most of the county. There are a handful of very small towns elsewhere in the county. Although they are not far from the county seat and are linked to it in many ways, it is probably stretching things to consider them part of a single "community." I should add that the problem of defining the term "community" as a subject of empirical study has vexed social scientists for many years, and I aspired to no conceptual breakthrough in this regard. My interest was in finding a research site where the jurisdiction of the court was roughly congruent with a social unit comprising a set of meaningful interactions and relationships. 
injury cases to court. When a minister filed a personal injury suit in Sander County after having slipped and fallen at a school, there were, in the words of one local observer:

[A] lot of people who are resentful for it, because . . .

he chose to sue. There's been, you know, not hard

feelings, just some strange intangible things. . . .

How can one explain these troubled perceptions of personal injury litigation in a community where personal injury actions were in fact so seldom brought? The answer lies partly in culturally-conditioned ideas of what constitutes an injury and how conflicts over injuries should be handled. The answer is also found in changes that were occurring in the social structure of Sander County at the time of this study and in challenges to the traditional order that were being raised by newly arrived "outsiders." The local trial court was potentially an important battleground in the clash of cultures, for it could be called on to recognize claims that traditional norms stigmatized in the strongest possible terms. ${ }^{4}$

\section{SOCIAL CHANGES AND THE SENSE OF COMMUNITY}

Sander County in the late 1970s was a society that was strongly rooted in its rural past yet undergoing economic and social changes of major proportions. It was a small county (between 20,000 and 30,000 population in the 1970s), with more than half its population concentrated in its county seat and the rest in several much smaller towns and rural areas. Agriculture was still central to county life. Sander County had 10 percent more of its land in farms in the mid-1970s than did the state of Illinois as a whole, but the number of farms in Sander County had decreased by more than one-third over the preceding twenty years while their average size had grown by almost half. Rising costs, land values, and taxes had been accompanied by an increase in the mechanization of agriculture in Sander County, and the older, smaller farming operations were being rapidly transformed. At the same time, a few large manufacturing plants had brought blue collar employees from other areas to work (but not always to live) in Sander County. Also, a local canning plant had for many years employed seasonal migrant workers, many of whom were Latinos. In

4 Hostility towards personal injury litigation as a form of "hyperlexis" may also have been influenced in Sander County by mass media treatment of this form of legal claim. Yet the attitudes and antagonisms I describe had deep roots in the culture of Sander County itself as well as in the popular culture of the country as a whole. A critical appraisal of the hyperlexis literature, which parallels this discussion in some respects, is found in Galanter (1983). 
recent years, however, a variety of "outsiders" had come to stay permanently in Sander County, and the face of the local society was gradually changing.

To some extent these changes had been deliberately planned by local leaders, for it was thought that the large manufacturing plants would revitalize the local economy. Yet from the beginning there had also been a sense of foreboding. In the words of one older farmer:

A guy that I used to do business with told me when he saw this plant coming in down here that he felt real bad for the community. He said, that's gonna be the end of your community, he said, because you get too many people in that don't have roots in anything. And I didn't think too much about it at the time, but I can understand what he was talking about now. I know that to some extent, at least, this is true. Not that there haven't been some real good people come in, I don't mean that. But I think you get quite a number of a certain element that you've never had before.

Others were more blunt about the "certain element" that had entered Sander County: union members, southerners and southwesterners, blacks, and Latinos. One long-time rural resident told us, "I think there's too many Commies around. I think this country takes too many people in, don't you? . . . That's why this country's going to the dogs." Many Sander County residents referred nostalgically to the days when they could walk down Main Street and see none but familiar faces. Now there were many strangers. An elderly woman from a farming family, who was struggling to preserve her farm in the face of rising taxes and operating costs, spoke in troubled tones of going into the post office and seeing Spanish-speaking workers mailing locally-earned money to families outside the country. "This," she said, "I don't like." Another woman, also a long-time resident, spoke of the changing appearance of the town:

[It was] lots different than it is right now. For one thing, I think we knew everybody in town. If you walked uptown you could speak to every single person on the street. It just wasn't at all like it is today. Another thing, the stores were different. We have so many places now that are foreign, Mexican, and health spas, which we're not very happy about, most of us. My mother was going uptown here a year ago and didn't feel very well when she got up to State Street. But she just kept going, and I thought it was terrible because the whole north side of town was the kind of place that you wouldn't want to go into for information 
or for help. Mostly because we've not grown up with an area where there were any foreign people at all.

There was also in the late 1970s a pervasive sense of a breakdown in the traditional relationships and reciprocities that had characterized life in Sander County. As one elderly farmer told me:

It used to be I could tell you any place in Sander County where it was, but I can't now because I don't know who lives on them. . . . And as I say in the last 20 years people don't change work like they used toor in the last 30 years. Everybody's got big equipment, they do all their own work so they don't have to change labor. Like years ago ... . why you had about 15 or 20 farmers together doing the exchange and all.

Many Sander County residents with farming backgrounds had warm memories of the harvest season, when groups of neighbors got together to share work and food:

When we had the threshing run, the dining room table it stretched a full 17 feet of the dining room, and guys would come in like hungry wolves, you know, at dinner time and supper again the same thing. . . . And they'd fire the engine up and have it ready to start running by 7:00. . . . You know, it was quite a sight to see that old steam engine coming down the road. I don't know, while I never want to be doing it again, I still gotta get kind of a kick out of watching a steam engine operate.

And all could remember socializing with other farming families on Saturday evenings during the summertime. In the words of two long-time farmers:

A: Well, on Saturday night they used to come into town, and the farmers would be lined up along the sidewalk with an ice cream cone or maybe a glass of beer or something. . . .

B: If you met one to three people, you'd get all the news in the neighborhood. . . .

A: If you go downtown now, anytime, I doubt if you'll see half a dozen people that you know. I mean to what you say sit down and really, really know them.

B: You practically knew everybody.

A. That's right, but you don't now.

B: No, no, no. If you go down Saturday night . . .

A: Everything is dead.

\section{THE STUDY}

I shall argue in this article that perceptions of personal injury claims in Sander County were strongly influenced by 
these social changes as local residents experienced them and by the sense that traditional relationships and exchanges in the community were gradually disintegrating. ${ }^{5}$ I cannot say that the frequent condemnation of personal injury litigation elsewhere in the United States is linked to a similar set of social processes, but investigation in other settings may disclose some parallels. The sense of community can take many forms in American society, and when members of a community feel threatened by change, their response may be broadly similar to the kind of response I describe here.

My discussion is based on fieldwork conducted from 1978 to 1980. Besides doing background research and immersing myself in the community and in the workings of the Sander County Court, I collected data for the study in three ways: (1) A sample of civil case files opened in 1975 and 1976 was drawn and analyzed. ${ }^{6}$ (2) Plaintiffs and defendants in a subsample of these civil cases were contacted and interviewed in broad-ranging, semi-structured conversations. ${ }^{7}$ (3) Strategically placed "community observers" were identified and interviewed at length. These were individuals who had particular insights into different groups, settings, occupations, or activities in the community. ${ }^{8}$ Discussions with them touched on various aspects of the community, including the ways in which the relationships, situations, and problems that might give rise to litigated cases were handled when the court was not used. The insights derived from the community observer

5 The sense of social change and disintegration in Sander County helped crystallize a set of values opposed to personal injury litigation. These values were almost certainly rooted in long established norms, but the targets of their expression and the intensity with which they were asserted may have been new. This article focuses on how and why such values came to be expressed and acutely felt in the late 1970s by many Sander County residents. See note 19 infra.

6 A 20\% sample was taken for the years 1975-1976 within each of 12 civil categories mandated by the Administrative Office of the Illinois Courts: (1) Law (claim over $\$ 15,000$ ), (2) Law (claim $\$ 15,000$ or less), (3) Chancery, (4) Miscellaneous Remedies, (5) Eminent Domain, (6) Estates, (7) Tax, (8) Municipal Corporations, (9) Mental Health, (10) Divorce, (11) Family, (12) Small Claims. After the sample was drawn, the cases were reclassified into the substantive categories referred to throughout this article.

7 Parties in 66 cases were interviewed. Wherever possible, all parties to each case were included. Particular attention was given to the individuals themselves, the relationship between them, and to the origin, development, and outcome of each case.

8 Among the 71 community observers were judges, lawyers, teachers, ministers, farmers, a beautician, a barber, city and county officials, a funeral parlor operator, youth workers, social service workers, various "ordinary citizens" from different segments of the community, a union steward, a management representative, agricultural extension workers, doctors, a newspaper reporter, the members of a rescue squad, and others. 
interviews thus provided a broader social and cultural context for the insights derived from the court-based research.

Personal injuries were one of four major substantive topics selected to receive special attention in this study. ${ }^{9}$ It soon became apparent, however, that personal injuries were viewed quite differently from the other topics, and the differences appeared to be related to the fundamental social changes that were taking place in Sander County. Focusing on personal injuries in this article makes it possible to examine the role played by formal law in mediating relationships between different groups in a changing society and to consider why the rare use of formal legal institutions for certain purposes can evoke strong concern and reaction in a community. The answer, I shall suggest, lies in the ideological responses of longtime residents of Sander County whose values and assumptions were subjected to profound challenges by what they saw as the intrusion of newcomers into their close-knit society.

\section{INJURIES AND INDIVIDUALISM}

For many of the residents of Sander County, exposure to the risk of physical injury was simply an accepted part of life. In a primarily agricultural community, which depended on hard physical work and the use of dangerous implements and machinery, such risks were unavoidable. Farmers in Sander County told many stories of terrible injuries caused by hazardous farming equipment, vehicles of different kinds, and other dangers that were associated with their means of obtaining a livelihood. There was a feeling among many in Sander County-particularly among those from a farming background-that injuries were an ever-present possibility, although prudent persons could protect themselves much of the time by taking proper precautions.

It would be accurate to characterize the traditional values associated with personal injuries in Sander County as individualistic, but individualism may be of at least two types. A rights-oriented individualism is consistent with an aggressive demand for compensation (or other remedies) when important interests are perceived to have been violated. By contrast, an individualism emphasizing self-sufficiency and personal responsibility rather than rights is consistent with the expectation that people should ordinarily provide their own

9 The other three substantive areas were injuries to reputation, contracts, and marital problems. 
protection against injuries and should personally absorb the consequences of harms they fail to ward off. ${ }^{10}$

It is not clear why the brand of individualism that developed over the years in Sander County emphasized selfsufficiency rather than rights and remedies, but with respect to personal injuries at least, there can be no doubt that this had occurred. If the values associated with this form of individualism originated in an earlier face-to-face community dominated by economically self-sufficient farmers and merchants, they remained vitally important to many of the long-time Sander County residents even at the time of this study. For them, injuries were viewed in relation to the victims, their fate, and their ability to protect themselves. Injuries were not viewed in terms of conflict or potential conflict between victims and other persons, nor was there much sympathy for those who sought to characterize the situation in such terms. To the traditional individualists of Sander County, transforming a personal injury into a claim against someone else was an attempt to escape responsibility for one's own actions. The psychology of contributory negligence and assumption of risk had deep roots in the local culture. The critical fact of personal injuries in most cases was that the victims probably could have prevented them if they had been more careful, even if others were to some degree at fault. This fact alone is an important reason why it was considered inappropriate for injured persons to attempt to transform their misfortune into a demand for compensation or to view it as an occasion for interpersonal conflict.

Attitudes toward money also help explain the feelings of long-time residents of Sander County toward personal injury claimants. While there might be sympathy for those who suffered such injuries, it was considered highly improper to try to "cash in" on them through claims for damages. Money was viewed as something one acquired through long hours of hard work, not by exhibiting one's misfortunes to a judge or jury or other third party, even when the injuries were clearly caused by the wrongful behavior of another. Such attitudes were reinforced by the pervasive sense of living in what had long been a small and close-knit community. In such a community, potential plaintiffs and defendants are likely to know each other, at least by reputation, or to have acquaintances in

10 This distinction between the two types of individualism emerged from an ongoing dialogue with Fred Konefsky, whose contribution to this conceptualization I gratefully acknowledge. 
common. It is probable that they will interact in the future, if not directly then through friends and relatives. In these circumstances it is, at best, awkward to sue or otherwise assert a claim. In addition, in a small community one cannot hide the fact of a suit for damages, and the disapproving attitudes of others are likely to be keenly felt. Thus, I was frequently assured that local residents who were mindful of community pressures generally reacted to cases of personal injury, even those that might give rise to liability in tort, in a "level-headed" and "realistic" way. By this it was meant that they would not sue or even, in most cases, demand compensation extrajudicially from anyone except, perhaps, their own insurance companies. ${ }^{11}$

Given the negative views that local juries adopted toward personal injury cases, terms such as "realistic" for those who avoided litigation were indeed well chosen. Judges, lawyers, and laypersons all told me that civil trial juries in the county reflected-and thus reinforced-the most conservative values and attitudes toward personal injury litigation. Awards were very low and suspicion of personal injury plaintiffs was very high. A local insurance adjuster told me:

[T] he jury will be people from right around here that are, a good share of them will be farmers, and they've been out there slaving away for every penny they've got and they aren't about to just give it away to make that free gift to anybody.

And one of the leading local trial lawyers observed:

[T] here's a natural feeling, what's this son of a bitch doing here? Why is he taking our time? Why is he

11 I heard of only a few cases where injured persons negotiated compensatory payments from the liability insurance of the party responsible for their harm. In these cases expectations (or demands) appeared to be modest. One involved a woman who lived on a farm. When visiting a neighbor's house, she fell down the basement stairs because of a negligently installed door, fractured her skull, was unconscious for three days, and was in intensive care for five days. As a result of the accident she suffered a permanent loss of her sense of smell and a substantial (almost total) impairment of her sense of taste. Her husband, a successful young farmer, told me that their own insurance did not cover the injury. Their neighbor had liability insurance, which paid only $\$ 1000$ (the hospital bills alone were approximately $\$ 2500$ ). Nevertheless, they never considered seeking greater compensation from their neighbor or the neighbor's insurance company:

We were thankful that she recovered as well as she did.... We never considered a lawsuit there at all. I don't know what other people would have done in the case. Possibly that insurance company would have paid the total medical if we would have just, well, I have a brother who is an attorney, could have just wrote them a letter maybe. But, I don't know, we just didn't do it, that's all.

Further discussion of the role of insurance in the handling of personal injuries in Sander County appears in the next section. 
trying to look for something for nothing? . . . So I've got to overcome that. That's a natural prejudice in a small [community], they don't have that natural prejudice in Cook County. But you do have it out here. So first I've got to sell the jury on the fact that this man's tried every way or this woman's tried every way to get justice and she couldn't. And they now come to you for their big day. . . . And then you try like hell to show that they're one of you, they've lived here and this and that.

The prospects for trying a personal injury case before a local jury, he concluded, were so discouraging that, "If I can figure out a way not to try a case in [this] county for injury, I try to."

Where there was no alternative as to venue, potential plaintiffs typically resigned themselves to nonjudicial settlements without any thought of litigation. And, as I have already suggested, for many in the community the possibility of litigation was not considered in any case. One woman I spoke with had lost her child in an automobile accident. She settled the case for $\$ 12,000$ without filing a claim, yet she was sure that this amount was much less than she could have obtained through a lawsuit. She told me that since she and her family knew they were going to stay permanently in the community, the pressure of the local value system foreclosed the possibility of taking the matter to court:

One of the reasons that I was extremely hesitant to sue was because of the community pressure. ... Local people in this community are not impressed when you tell them that you're involved in a lawsuit. .. . That really turns them off. . . . They're not impressed with people who don't earn their own way. And that's taking money that they're not sure that you deserve.

Others had so internalized this value system that they followed its dictates even when community pressures did not exist. A doctor told me that one of his patients was seriously burned during a trip out of state when an airline stewardess spilled hot coffee on her legs, causing permanent discoloration of her skin. This woman refused to contact a lawyer and instead settled directly with the airline for medical expenses and the cost of the one-week vacation she had missed. Regarding the possibility of taking formal legal action to seek a more substantial award, she said simply, "We don't do that." This same attitude may help to explain the apparent reluctance of local residents to assert claims against other potential defendants from outside Sander County, such as negligent drivers or businesses or manufacturers. 
Thus, if we consider the range of traditional responses to personal injuries in Sander County, we find, first of all, a great deal of self-reliant behavior. Injured persons typically responded to injuries without taking any overt action, either because they did not view the problem in terms of a claim against or conflict with another person or because membership in a small, close-knit community inhibited them from asserting a claim that would be socially disapproved. Some sought compensation through direct discussions with the other party, but such behavior was considered atypical. When sympathy or advice was sought, many turned to friends, neighbors, relatives, and physicians. The County Health Department, the mayor, and city council representatives also reported that injured persons occasionally sought them out, particularly when the injuries were caused by hazards that might endanger others. In such cases, the goal was generally to see the hazard removed for the benefit of the public rather than to seek compensation or otherwise advance personal interests.

\section{INSURING AGAINST INJURIES}

Persons who had been injured often sought compensation from their own health and accident insurance without even considering the possibility of a claim against another party or another insurance company. As a local insurance adjuster told me:

We have some people that have had their kid injured on our insured's property, and they were not our insured. And we call up and offer to pay their bills, because our insured has called and said my kid Tommy cracked that kid over the head with a shovel and they hauled him off to the hospital. And I called the people and say we have medical coverage and they are absolutely floored, some of them, that it never even crossed their minds. They were just going to turn it in to their own little insurance, their health insurance, and not do anything about it whatsoever, especially if [Tommy's parents] are close friends. . . .

By moving quickly to pay compensation in such cases before claims could arise, this adjuster believed that she prevented disputes and litigation. It helped, too, that the adjuster and the parties to an accident, even an automobile accident, usually knew each other:

In Chicago, all those people don't know the guy next door to them, much less the guy they had the wreck with. And right here in town, if you don't know the people, you probably know their neighbor or some of 
their family or you can find out real quick who they are or where they are.

The contrast between injuries in a face-to-face community and in a metropolis like Chicago was drawn in explicit terms:

I think things are pretty calm and peaceful as, say, compared to Chicago. Now I have talked to some of the adjusters in that area from time to time and I know, well, and we have our own insureds that go in there and get in an accident in Chicago, and we'll have a lawsuit or at least have an attorney . . . on the claim within a day or maybe two days of the accident even happening. Sometimes our insured has not any more than called back and said I've had a wreck but I don't even know who it was with. And before you can do anything, even get a police report or anything, why you'll get a letter from the attorney. And that would never, that rarely ever happens around here.

This adjuster estimated that over the past 15 years, her office had been involved in no more than 10 automobile-related lawsuits, an extraordinarily low number compared to the frequency of such cases in other jurisdictions. ${ }^{12}$ Of course, once an insurance company has paid compensation to its insured, it may exercise its right of subrogation against the party that caused the accident, and one might expect insurance companies to be unaffected by local values opposing the assertion or litigation of injury claims. It is not entirely clear why insurance companies, like individuals, seldom brought personal injury actions in Sander County, but there are some clues. This particular adjuster, who had grown up in Sander County, shared the local value system. Although she did not decide whether to bring suit as a subrogee, she may well have affected the decisions of her central office by her own perceptions and by her handling of the people and documents in particular cases. Furthermore, her insurance company was connected to the Farm Bureau, a membership organization to which most local farmers belonged. The evident popularity of this insurance carrier in Sander County (over 75 percent of the eligible farm families were estimated to be members of the Farm Bureau; it is not known how many members carried the

12 In Sander County as a whole, the litigation rate for automobile-related personal injury cases in 1975-76 was 0.88 cases each year per 1,000 population. For all automobile-related tort actions, including those where there was no personal injury claim, the litigation rate was 1.87 cases per 1,000 population. In the absence of reliable or meaningful comparative data, it is difficult to say how low or high these county-wide rates are; but my hunch is that these are rather low for a jurisdiction in which no-fault approaches were not used for motor vehicle cases. 
insurance, but the percentage was apparently high) meant that injuries in many cases may have involved two parties covered by the same insurance company.

Occasionally, an insurance company did bring suit in the name of its insured, but given the unsympathetic attitudes of local juries, such lawsuits seldom met with success in Sander County. The adjuster mentioned above told me of a farm worker from Oklahoma who was harvesting peas for a local cannery. He stopped to lie down and rest in the high grass near the road and was run over by her insured, who was driving a pick-up truck and had swerved slightly off the road to avoid a large combine. When the fieldworker's insurance carrier sought compensation, the local adjuster refused, claiming that the injured man should not have been lying in the grass near the road and could not have been seen by her insured, who, she insisted, was driving carefully. The case went to trial and a jury composed largely of local farmers was drawn:

I was not even in there because our lawyers that represent us said, how many of those people do you know out there? And I said, I can give you the first name of everybody on the jury. He said, you stay over there in the library ... don't let them see you. ... . So I stayed out in my little corner and listened to what went on and we won, we didn't pay 5 cents on it.

Thus, even a lawsuit involving insurance companies on both sides was ultimately resolved in a manner that accorded with traditional values. The insurance companies' knowledge of jury attitudes in Sander County undoubtedly affected their handling of most injury cases.

\section{LAWYERS AND LOCAL VALUES}

Sander County attorneys reported that personal injury cases came to them with some regularity, although they also felt that many injury victims never consulted an attorney but settled directly with insurance companies for less than they should have received. When these attorneys were consulted, it was by people who, in the opinion of the attorneys, had real, nonfrivolous grievances, but the result was seldom formal legal action. Most personal injury cases were resolved, as they are elsewhere (Ross, 1970), through informal negotiation. Formal judicial procedures were initiated primarily to prod the other side to negotiate seriously or when it became necessary to preserve a claim before it would be barred by the statute of limitations. The negotiating process was, of course, strongly influenced by the parties' shared knowledge of likely juror 
reaction if the case actually went to trial. Thus, plaintiffs found negotiated settlements relatively attractive even when the terms were not particularly favorable.

But expectations regarding the outcome of litigation were probably not the only reason that members of the local bar so seldom filed personal injury cases. To some extent Sander County lawyers, many of whom were born and raised in the area, shared the local tendency to censure those who aggressively asserted personal injury claims. One attorney, for example, described client attitudes toward injury claims in the following terms: "A lot of people are more conducive to settlement here just because they're attempting to be fair as opposed to making a fast buck." Yet this same attorney admitted that informal settlements were often for small amounts of money and were usually limited to medical expenses, without any "general" damages whatever. ${ }^{13} \mathrm{His}$ characterization of such outcomes as "fair" suggests an internalization of local values even on the part of those whose professional role it was to assert claims on behalf of tort plaintiffs.

The local bar was widely perceived as inhospitable to personal injury claimants, not only because there were few tort specialists but because Sander County lawyers were seen as closely linked to the kinds of individuals and businesses against whom tort actions were typically brought. Although plaintiffs hired Sander County attorneys in $\mathbf{7 2 . 5}$ percent of all non-tort actions filed locally in which plaintiffs were represented by counsel, they did so in only 12.5 percent of the tort cases. ${ }^{14}$ One lawyer, who was frequently consulted by potential tort plaintiffs, lived across the county line in a small town outside of Sander County. He told me, "I get a lot of cases where people just don't want to be involved with the, they perceive it to be

13 This is particularly striking since Laurence Ross' observation of insurance company settlement practices in automobile accident cases suggests that general damages are a standard part of the settlement "package" and are rather routinely calculated "for the most part . . . [by] multiplying the medical bills by a tacitly but generally accepted arbitrary constant" (Ross, 1970: 239).

14 These figures are from a sample of cases for the years 1975-1976. See note 6 supra. From these data alone one cannot conclude that Sander County attorneys were less often approached by potential personal injury plaintiffs, since the data consist only of cases that were filed and tell us nothing about cases brought to an attorney but not filed. We know that Sander County attorneys were sometimes reluctant to bring such actions even when approached by prospective plaintiffs. Attorneys elsewhere, particularly those who were tort specialists, may not have shared this reluctance and may have filed a higher proportion of the Sander County claims that were brought to them. 
the hierarchy of Sander County. . . I'm not part of the establishment."

Thus, even from the perspective of insurance company personnel and attorneys, who were most likely to witness the entry of personal injury cases into the formal legal system in Sander County, it is clear that the local culture tended in many ways to deter litigation. And when personal injury cases were formally filed, it usually was no more than another step in an ongoing negotiation process.

Why was the litigation of personal injury cases in Sander County subjected to disapproval so pervasive that it inhibited the assertion of claims at all stages, from the moment injuries occurred and were perceived to the time parties stood at the very threshold of the formal legal system? The answer, I shall argue, lies partly in the role of the Sander County Court in a changing social system and partly in the nature of the personal injury claim itself.

\section{THE USE OF THE COURT}

In the recent literature on dispute processing and conflict resolution, various typologies of conflict-handling forums and procedures have been proposed. Such typologies usually include courts, arbitrators, mediators, and ombudsmen, as well as two-party and one-party procedures such as negotiation, selfhelp, avoidance, and "lumping it" (see, e.g., typologies in Abel, 1973; Felstiner, 1974; Steele, 1975; Nader and Todd, 1978; Black and Baumgartner, 1983; Galanter, 1983). Analyses of these alternative approaches incorporate a number of variables that critically affect the ways in which conflict is handled and transformed. Such variables include, among others, procedural formality, the power and authority of the intervenor, the coerciveness of the proceedings, the range and severity of outcomes, role differentiation and specialization of third parties and advocates, cost factors, time required, the scope of the inquiry, language specialization, and the quality of the evidence that will be heard. When variables such as these are used to analyze various approaches to conflict resolution, the result is typically a continuum ranging from the most formal, specialized, functionally differentiated, and costly approaches to the most informal, accessible, undifferentiated, and inexpensive. The court as a forum for dispute processing and conflict resolution is typically placed at the costly, formalistic end of such continua. 
Yet common sense and empirical investigations consistently remind us that trial courts rarely employ the adjudicative procedures that make them a symbol of extreme formalism. Very few of the complaints filed in courts are tried and adjudicated. Most are settled through bilateral negotiations of the parties or, occasionally, through the efforts of a judge who encourages the parties to reach an agreement without going to trial. This was true of the Sander County Court, as it is of courts elsewhere, and it applied with particular force to the relatively infrequent personal injury complaints that were filed in Sander County. Adjudication on the merits was extremely rare. In my sample only one of fifteen personal injury cases went to trial, and the judges and lawyers to whom I talked confirmed the generality of this pattern. Yet the court did play a crucial role in the handling of personal injury conflicts. It did so by providing what was perhaps the only setting in which meaningful and effective procedures of any kind could be applied. To understand why this was so, we must examine some distinctive characteristics of the relationships between the parties in the personal injury cases that were litigated in Sander County.

Among the relative handful of personal injury cases filed in the Sander County Court, almost all shared a common feature: the parties were separated by either geographic or social "distance" that could not be bridged by any conflict resolution process short of litigation. ${ }^{15}$ In at least half of the fifteen personal injury cases in the sample, the plaintiff and the defendant resided in different counties or states. These cases were evenly split between instances in which the plaintiff, on the one hand, and the defendant, on the other hand, was a local resident. In either situation, geographic distance meant that the parties almost certainly belonged to different communities and different social networks. Informal responses by the injured party, whether they involved attempts to negotiate, to mediate, or even to retaliate by gossip, were likely to be frustrated since channels for communication and shared value systems and acquaintance networks were unlikely to exist. This is reflected in the disproportionate presence of parties from outside the county on the personal injury docket. ${ }^{16}$

15 In this discussion of geographic and social distance and their impact on patterns of legal behavior, I draw upon a body of theory that has been developed in several earlier studies. See Black (1976); Perin (1977); Engel (1978); Todd (1978); Greenhouse (1982).

16 The disproportionate number of cases involving geographically distant adversaries is especially striking when one considers the relative infrequency 
A more elusive but no less significant form of distance was suggested by interviews with the parties as well as by the court documents in several personal injury cases. In these cases, it became apparent that "social distance," which was less tangible but just as hard to bridge as geographic distance, separated the parties even when they were neighbors.

Social distance could take many forms in Sander County. In one personal injury case, the plaintiff, who lived in one of the outlying towns in Sander County, described himself as an outsider to the community although he had lived there almost all his life. He was a Democrat in a conservative Republican town; he was of German extraction in a community where persons of Norwegian descent were extremely clannish and exclusive; he was a part-time tavernkeeper in a locality where taverns were popular but their owners were not socially esteemed; the opposing party was a "higher up" in the organization for which they both worked, and there was a long history of "bad blood" between them.

In a second personal injury case, a Mexican immigrant and his family sued a tavernkeeper under the Illinois Dram Shop Act for injuries he had suffered as a bystander in a barroom scuffle. Latino immigration into the community had, as we have seen, increased greatly in recent years to the displeasure of many local residents. Cultural misunderstandings and prejudice ran high, and little sympathy could be expected for a Latino who was injured in the course of a barroom fight. Thus, the plaintiff's wife was quite worried about bringing the lawsuit. She feared that they would create more trouble for themselves and told me, "I was afraid that maybe they'd say our kind of people are just trying to get their hands on money any way we could . . ." The decision to sue was made because they believed that people behind the bar had contributed to the injury by passing $\dot{a}$ weapon to the man who had struck the plaintiff (although, under the Dram Shop Act, the tavern could have been found liable without fault), and because they saw no other way to recover the income they had lost when the plaintiff's injury had kept him from working.

The tavernkeeper, who considered herself a member of the social underclass (although in a different sense from the

of interaction between persons living in separate counties and states as compared to persons living in the same county or town. In absolute terms, injurious interactions must have occurred far more frequently between neighbors than between distant strangers, yet injurious interactions between distant strangers ended up in the Sander County Court about as often as those involving local residents (compare Engel, 1978: 142-44). 
Mexican immigrants), was bitter about the case and about the Dram Shop Act. When I asked her how the plaintiffs had known that she was liable under the Act, she answered, "I haven't any idea. How do they know about a lot of things is beyond me. They know how to come here without papers and get a job or go on welfare. They are not too dumb, I guess."

In this case, then, the two parties were separated from each other and from the community by a great chasm of social distance. One person was set apart from the general community by ethnicity and was well aware that his injuries were unlikely to be regarded with sympathy. The other party was also, by self-description, a "second class citizen." As a tavernkeeper, she told me, "you come up against many obstacles, prejudices, and hard times, you wouldn't believe." Both descriptions of social alienation were accurate. Yet the defendant had an established place in the traditional social order. She owned a small business in a town dominated by the ethos of individual enterprise. Her line of work was widely recognized and accepted, although not accorded great prestige, in a community where taverns were among the most important social centers. Her acquisition of Dram Shop insurance made her a "deep pocket" comparable to other local business enterprises that might provide substantial compensation in appropriate cases to injured persons. The plaintiffs in this case, far more than the defendant, were truly social "outsiders" in Sander County. For them, nonjudicial approaches appeared hopeless, and passively absorbing the injury was too costly. Only formal legal action provided a channel for communication between the two parties, and this ultimately led, despite the defendant's reluctance, to settlement.

Social distance also played a part in an action brought by a woman on behalf of her five-year-old daughter, who had suffered internal injuries when a large trash container fell on her. The little girl had been climbing on the trash container, which was located in back of an automobile showroom. The plaintiff and her husband were described by their adversaries as the kind of people who were constantly in financial trouble and always trying to live off somebody else's money. The plaintiff herself stated frankly that they were outsiders in the community, ignored or avoided even by their next-door neighbors. As she put it, "Everybody in this town seems to know everybody else's business . . . but they don't know you."

Her socially marginal status in the community precluded any significant form of nonjudicial conflict resolution with the 
auto dealer or the disposal company, and the matter went to the Sander County Court, where the $\$ 150,000$ lawsuit was eventually settled for $\$ 3,000$. Since initiating the lawsuit, the plaintiff had become a born-again Christian and, from her new perspective on life, came to regret her decision to litigate. The little money they had obtained simply caused her to fight with her husband, who sometimes beat her. She came to believe that she should not have sued, although she did feel that her lawsuit had done some good. After it was concluded, she observed, signs were posted near all such trash containers warning that children should not play on them.

In my interviews with local residents, officials, community leaders, and legal professionals, I presented the fact situation from this last case (in a slightly different form, to protect the privacy and identity of the original participants) and asked them how similar cases were handled in the segments of the community with which they were familiar. From our discussion of this matter there emerged two distinct patterns of behavior which, the interviewees suggested, turned on the extent to which the aggrieved party was integrated into the community. If the parents of the injured child were long-time residents who were a part of the local society and shared its prevailing value system, the consensus was that they would typically take little or no action of any sort. Injuries, as we have seen, were common in a rural community, and the parents would tend to blame themselves for not watching the child more carefully or, as one interviewee put it, would "figure that the kid ought to be sharp enough to stay away" from the hazard. On the other hand, if the parents of the injured child were newcomers to the community, and especially if they were factory workers employed in the area's newly established industrial plants, it was suggested that their behavior would be quite different. One union steward assured me that the workers he knew typically viewed such situations in terms of a potential lawsuit and, at the least, would aggressively seek to have the auto dealer and the disposal company assume responsibility for the damages. Others described a kind of "fight-flight" reaction on the part of newcomers and industrial blue collar workers. One particularly perceptive minister said, "Those . . . that feel put down perceive everything in the light of another putdown and I think they would perceive this as a putdown. See, nobody really cares about us, they're just pushing us around again. And so we'll push back." He also noted, however, that it was equally likely that aggrieved 
individuals in this situation would simply move out of the community-the "flight" response.

There was, then, some agreement that responses involving the aggressive assertion of rights, if they occurred at all, would typically be initiated by newcomers to the community or by people who otherwise lacked a recognized place in the status hierarchy of Sander County. Such persons, in the words of a local schoolteacher, would regard the use of the court as a "leveler" that could mitigate the effects of social distance between themselves and the other side. Persons who were better integrated into the community, on the other hand, could rely on their established place in the social order to communicate grievances, stigmatize what they viewed as deviant behavior, press claims informally, or, because they felt comfortable enough psychologically and financially, to simply absorb the injury without any overt response whatever.

Interestingly, this was precisely the picture drawn for me by the evangelical minister who had converted the mother of the five-year-old girl to born-again Christianity. Lifelong residents of the community, he told me, reacted to stressful situations with more stability and less emotion than newcomers to the community who were less rooted and whose lives were filled with pressures and problems and what he called, "groping, searching, grasping." For this minister, born-again Christianity offered socially marginal people a form of contentment and stability that was denied them by their lack of a recognized position in the local society. He argued that external problems such as personal injuries were secondary to primary questions of religious faith. He told me, "[I]f we first of all get first things straightened out and that is our relationship with God and is our help from God, all of these other things will fall into order." This was precisely the message that the plaintiff in this case-and many other socially marginal people in the community like her-had come to accept. On this basis, many social outsiders in Sander County could rationalize passivity in the face of personal injuries, passivity that was at least outwardly similar to the typical responses of Sander County's long-time residents.

The picture of the Sander County Court that emerges from this brief overview of personal injury cases differs substantially from that which might be suggested by conventional typologies of conflict resolution alternatives. In processual terms litigation, although rare, was not strikingly different from its nonjudicial alternatives. It was characterized by informal 
negotiation, bargaining, and settlement in all but the extremely infrequent cases that actually went to trial. Yet these processes occurred only as a result of the filing of a formal legal action. Because of the distance separating the parties, nonjudicial approaches, even with the participation of lawyers, sometimes failed to resolve the conflict. Resorting to the Sander County Court could vest socially marginal persons with additional weight and stature because it offered them access to the levers of judicial compulsion. The very act of filing a civil complaint, without much more, made them persons whom the other side must recognize, whose words the other side must hear, and whose claims the other side must consider. The civil trial court, by virtue of its legal authority over all persons within its jurisdiction, was able to bridge procedurally the gaps that separated people and social groups. In a pluralistic social setting, the court could provide, in the cases that reached it, a forum where communication between disparate people and groups could take place. In so doing, it substituted for conflicthandling mechanisms which served the well-integrated dominant group but which became ineffective for persons who were beyond the boundaries of the traditional community.

The communication that the court facilitated could, however, give rise to anger and frustration. Plaintiffs often viewed the process negatively, because even when they went to court they could not escape the rigid constraints imposed by a community unsympathetic to claims for damages in personal injury cases. Thus, the plaintiff whom I have described as a Democrat in a Republican town told me that the experience of filing and settling a personal injury claim was "disgusting . . . a lot of wasted time." Low pretrial settlements were, not surprisingly, the rule.

Defendants viewed the process negatively because they were accustomed to a system of conflict resolution that screened out personal injury cases long before they reached the courthouse. Even though settlements might turn out to be low, defendants resented the fact that personal injuries had in the first place been viewed as an occasion to assert a claim against them, much less a formal lawsuit. Being forced to respond in court was particularly galling when the claimant turned out to be a person whom the core members of the community viewed with dislike or disdain.

In short, the Sander County Court was able to bridge gaps between parties to personal injury cases and to promote communication between those separated by social or geographic 
distance. It did so, however, by coercion, and its outcomes (particularly when both parties resided in the community) tended to exacerbate rather than ameliorate social conflict. In the court's very success as a mechanism for conflict resolution we may, therefore, find a partial explanation for the stigmatization of personal injury litigation in Sander County.

\section{THE PRESERVATION AND DESTRUCTION OF A COMMUNITY}

In rural and archaic Japan . . . people used to believe that calamity that attacked the community had its origin in an alien factor inside the community as well as outside it. The malevolent factor accumulated in the community. It was related also to the sins committed wittingly or unwittingly by members of the community. In order to avoid the disastrous influence of the polluted element, it was necessary for the community to give the element form and to send it away beyond the limits of the village. However, the introduction of the alien element, which could turn into calamity at any time, was absolutely necessary for the growth of the crops. Thus the need for the alien factor had two facets which appear contradictory to each other on the surface: that is, the introduction of the negative element of expiation as well as the positive element of crop fertility (Yamaguchi, 1977: 154).

The social and economic life of Sander County had undergone major changes in the years preceding this study, and the impact of those changes on the world view of local residents and on the normative structure of the community as a whole was profound. Small single family farms were gradually giving way to larger consolidated agricultural operations owned by distant and anonymous persons or corporations. The new and sizeable manufacturing plants, together with some of the older local industries, now figured importantly in the economic life of Sander County and were the primary reasons why the population had become more heterogeneous and mobile.

These changes had important implications for traditional concepts of individualism and for the traditional relationships and reciprocities that had characterized the rural community. Self-sufficiency was less possible than before. Control over local lives was increasingly exercised by organizations based in other cities or states (there were even rumors that local farmlands were being purchased by unnamed foreign interests). Images of individual autonomy and community solidarity were 
challenged by the realities of externally-based economic and political power. Traditional forms of exchange could not be preserved where individuals no longer knew their neighbors' names, much less their backgrounds and their values. Local people tended to resent and perhaps to fear these changes in the local economic structure, but for the most part they believed that they were essential for the survival of the community. Some of the most critical changes had been the product of decisions made only after extensive deliberations by Sander County's elite. The infusion of new blood into the community-persons of diverse racial, ethnic, and cultural backgrounds-was a direct result of these decisions. The new residents were, in the eyes of many old-timers, an "alien element" whose introduction was, as in rural Japan, grudgingly recognized as "absolutely necessary" to preserve the well-being of the community.

The gradual decay of the old social order and the emergence of a plurality of cultures and races in Sander County produced a confusion of norms and of mechanisms for resolving conflict. New churches were established with congregations made up primarily of newcomers. Labor unions appeared on the scene, to the dismay and disgust of many of the old-timers. New taverns and other social centers catered to the newer arrivals. Governmental welfare and job training programs focused heavily (but not exclusively) on the newcomers. Newcomers frequently found themselves grouped in separate neighborhoods or apartment complexes and, in the case of blacks, there were reported attempts to exclude them from the community altogether. The newcomers brought to Sander County a social and cultural heterogeneity that it had not known before. Equally important, their very presence constituted a challenge to the older structure of norms and values generated by face-to-face relationships within the community.

\section{PERCEPTIONS OF CONTRACT AND PERSONAL INJURY CLAIMS}

The reaction of the local community to the assertion of different types of legal claims was profoundly affected by this proliferation of social, cultural, and normative systems. The contrast between reactions to claims based on breaches of contract and those based on personal injuries is especially striking. Contract actions in the Sander County Court were 
nearly ten times as numerous as personal injury actions. ${ }^{17}$ They involved, for the most part, efforts to collect payment for sales, services, and loans. One might expect that concerns about litigiousness in the community would focus upon this category of cases, which was known to be a frequent source of court filings. Yet I heard no complaints about contract plaintiffs being "greedy" or "sue happy" or "looking for the easy buck." Such criticisms were reserved exclusively for injured persons who made the relatively rare decision to press their claims in court.

In both tort and contract actions, claimants assert that a loss has been caused by the conduct of another. In contractual breaches, the defendant's alleged fault is usually a failure to conform to a standard agreed upon by the parties. ${ }^{18}$ In personal injury suits, the alleged fault is behavior that falls below a general societal standard applicable even in the absence of any prior agreement. Both are, of course, long-recognized types of actions. Both are "legitimate" in any formal sense of the word. Why is it, then, that actions to recover one type of loss were viewed with approval in Sander County, while far less frequent actions to recover the other type of loss were seen as symptomatic of a socially destructive trend toward the overuse of courts by greedy individuals and troublemakers? The answer appears to lie in the nature of the parties, in the social meanings of the underlying transactions, and in the symbolism of individuals and injuries in the changing social order.

Most of the contract litigation in Sander County involved debts to businesses for goods and services. Typically, the contracts that underlie such debts are quite different from the classic model of carefully considered offers and acceptances and freely negotiated exchanges. Yet many townspeople and farmers in the community saw such obligations as extremely important (Engel, 1980). They were associated in the popular mind with binding but informal kinds of indebtedness and with the sanctity of the promise. Long-time Sander County residents viewed their society as one that had traditionally been based on interdependencies and reciprocal exchanges among fellow residents. Reliance upon promises, including promises to pay for goods and services, was essential to the maintenance

17 Four percent of my case sample were personal injury cases and $37.5 \%$ were contract cases.

18 On many occasions, of course, courts import external standards into contracts and impose them on the parties regardless of their agreement or disagreement with such terms. 
of this kind of social system. One farmer expressed this core value succinctly: "Generally speaking, a farmer's word is good between farmers." Another farmer, who occasionally sold meat to neighbors and friends in his small town, told me:

We've done this for 20 years, and I have never lost one dime. I have never had one person not pay me, and I've had several of them went bankrupt, and so on and so forth. I really don't pay any attention to bookkeeping or what. I mean, if someone owes me, they owe me. And you know, I've never sent anybody a bill or anything. I mean, sooner or later they all pay.

In these interpersonal exchanges involving people well known to one another there was, it appears, some flexibility and allowance for hard times and other contingencies. On the other hand, there was a mutual recognition that debts must ultimately be paid. When I asked a number of people in the community about a case in which an individual failed to pay in full for construction of a fence, the typical reaction among longtime residents was that such a breach would simply not occur. Of course, breaches or perceptions of breaches did occur in Sander County and the result could be, in the words of one farmer, "fireworks." I was told stories of violent efforts at selfhelp by some aggrieved creditors, and it was clear that such efforts were not necessarily condemned in the community (Engel, 1980: 439-40). A member of the county sheriff's department observed that small unpaid debts of this kind were often viewed as matters for the police:

We see that quite a bit. They want us to go out and get the money. He owes it, there's an agreement, he violated the law.... Y You see, they feel that they shouldn't have to hire an attorney for something that's an agreement. It's a law, it should be acted upon. Therefore, we should go out and arrest the man and either have him arrested or by our mere presence, by the sheriff's department, a uniformed police officer, somebody with authority going out there and say, hey, you know, you should know that automatically these people give the money and that would be it. So therefore they wouldn't have to go to an attorney. Boy, a lot of people feel that.

Other creditors, particularly local merchants, doctors, and the telephone company, brought their claims not to the police but to the Sander County Court. In some cases, contract plaintiffs (many of whom were long-time residents) appeared to litigate specifically to enforce deeply felt values concerning debt and obligation. As one small businessman explained: 
I'm the type of a person that can get personally involved and a little hostile if somebody tries to put the screws to me. . . I I had it happen once for $\$ 5$ and I had it happen once for $\$ 12$. . . . I explained to them carefully to please believe me that it wasn't the money, because it would cost me more to collect it than it'd be worth, but because of the principle of it that I would definitely go to whatever means necessary, moneywise or whatever, to get it collected. And which I did.

Even those creditors for whom litigation was commonplace, such as the head of the local collection agency and an official of the telephone company, shared the perception that contract breaches were morally offensive. This view appeared to apply to transactions that were routinized and impersonal as well as to the more traditional exchanges between individuals who knew each other well. As the head of the collection agency said, "When you get to sitting here and you look at the thousands of dollars that you're trying to effect collection on and you know that there's a great percentage of them you'll never get and no one will get, it's gotta bother you. It's gotta bother you." Certainly, business creditors felt none of the hesitancy of potential tort plaintiffs about asserting claims and resorting to litigation if necessary. Equally important, the community approved the enforcement of such obligations as strongly as it condemned efforts to enforce tort claims. Contract litigation, even when it involved "routine" debt collection, differed from tort litigation in that it was seen as enforcing a core value of the traditional culture of Sander County: that promises should be kept and people should be held responsible when they broke their word.

\section{CONCLUSION}

In Sander County, the philosophy of individualism worked itself out quite differently in the areas of tort and contract. If personal injuries evoked values emphasizing self-sufficiency, contractual breaches evoked values emphasizing rights and remedies. Duties generated by contractual agreement were seen as sacrosanct and vital to the maintenance of the social order. Duties generated by socially imposed obligations to guard against injuring other people were seen as intrusions upon existing relationships, as pretexts for forced exchanges, as inappropriate attempts to redistribute wealth, and as limitations upon individual freedom.

These contrasting views of contract and tort-based claims took on special significance as a result of the fundamental 
social changes that Sander County had experienced. The newcomers brought with them conceptions of injuries, rights, and obligations that were quite different from those that had long prevailed. The traditional norms had no doubt played an important role in maintaining the customary social order by reinforcing longstanding patterns of behavior consistent with a parochial world view dominated by devotion to agriculture and small business. But the newcomers had no reason to share this world view or the normative structure associated with it. Indeed, as we shall see, they had good reason to reject it. ${ }^{19}$ Although they arrived on the scene, in a sense, to preserve the community and to save it from economic misfortune, the terms on which they were brought into Sander County-as migrant or industrial workers-had little to do with the customary forms of interaction and reciprocation that had given rise to the traditional normative order. The older norms concerning such matters as individual self-sufficiency, personal injuries, and contractual breaches had no special relevance or meaning given the interests of the newcomers. Although these norms impinged on the consciousness and behavior of the newcomers, they did so through the coercive forces and social sanctions that backed them up and not because the newcomers had accepted and internalized local values and attitudes.

Indeed, it was clear that in the changing society of Sander County, the older norms tended to operate to the distinct disadvantage of social outsiders and for the benefit of the insiders. Contract actions, premised on the traditional value that a person's word should be kept, tended to involve collection efforts by established persons or institutions ${ }^{20}$ against newcomers and socially marginal individuals. Such actions, as

19 Were personal injury lawsuits in the late 1970 s, although relatively infrequent, more common than they had been before the recent influx of social "outsiders" in Sander County? Because of the unavailability of reliable historical data, it is impossible to say, nor is the answer central to the analysis presented here. It is true that recent social changes in Sander County had brought striking juxtapositions of insiders and outsiders, and some increase in the frequency of tort claims may have resulted; but in earlier periods there may have been other kinds of outsiders as well, and some of them may have brought personal injury actions. In this article, I am interested in the past primarily as it existed in the minds of Sander County's citizens at the time of my study. It is clear that current perceptions of Sander County's history and traditions, whether accurate or not, played a crucial role in constructing and justifying responses to the problems that now faced the community, and such perceptions were often invoked to support the assertion of "traditional values" in opposition to behavior that provoked long-time residents.

20 Frequent plaintiffs in collection cases were doctors, hospitals, merchants, collection agencies, and the telephone company. Cases of this type constituted $76.5 \%$ of all contract actions. The remaining $23.5 \%$ of contract cases involved actions based on construction contracts, promissory notes, 
we have seen, were generally approved by the majority of Sander County residents and occurred with great frequency. Personal injury actions, on the other hand, were rooted in no such traditional value and, although such claims were infrequent, they were usually instituted by plaintiffs who were outsiders to the community against defendants who occupied symbolically important positions in Sander County society. Thus, a typical contract action involved a member of "the establishment" collecting a debt, while the typical personal injury action was an assault by an outsider upon the establishment at a point where a sufficient aggregation of capital existed to pay for an injury. This distinction helps to explain the stigmatization of personal injury litigation in Sander County as well as its infrequency and its ineffectiveness. ${ }^{21}$

Yet personal injury litigation in Sander County was not entirely dysfunctional for the traditional social order. The intrusion of "the stranger" into an enclosed system of customary law can serve to crystallize the awareness of norms that formerly existed in a preconscious or inarticulate state (See Fuller, 1969: 9-10 and Simmel, 1908/1971). Norms and values that once patterned behavior unthinkingly or intuitively must now be articulated, explained, and defended against the contrary values and expectations of the stranger to the community.

In Sander County, the entry of the stranger produced a new awareness (or perhaps a reconstruction) of the traditional normative order at the very moment when that order was subjected to its strongest and most devastating challenges. This process triggered a complex response by the community-a nostalgic yearning for the older world view now shattered beyond repair, a rearguard attempt to shore up the boundaries

wholesale transactions, and other less frequent kinds of contractual transactions.

21 Sander County tort and contract cases are not unique, of course, in these basic structurai differences. In other localities one might also expect to find that the majority of tort plaintiffs are individuals asserting claims against "deep pocket" defendants, while the majority of contract plaintiffs are business organizations attempting to collect debts from individuals. See, for example, Galanter (1974) and Yngvesson and Hennessey (1975). It is possible that outside of Sander County perceptions of the legitimacy and illegitimacy of contract and tort actions are also influenced by these basic structural differences. In Sander County, however, this set of distinctions between the parties to tort and contract actions combined with local reactions to recent societal changes to produce a powerful symbolism of insiders and outsiders and of injuries and individualism. The extent to which a similar symbolism may be found in other localities is a subject for further investigation. 
of the community against alien persons and ideas (compare Erikson, 1966), and a bitter acceptance of the fact that the "stranger" was in reality no longer outside the community but a necessary element brought in to preserve the community, and therefore a part of it.

Local responses to personal injury claims reflected these complexities. In part, local residents, by stigmatizing such claims, were merely defending the establishment from a relatively rare form of economic attack by social outsiders. In part, stigmatization branded the claimants as deviants from the community norms and therefore helped mark the social boundaries between old-timers and newcomers. Because the maintenance of such boundaries was increasingly difficult, however, and because the "alien element" had been deliberately imported into the community as a societal act of self-preservation, the stigmatization of such claims was also part of a broader and more subtle process of expiation (to borrow Yamaguchi's [1977] term), a process reminiscent of rituals and other procedures used in many societies to deal with problems of pollution associated with socially marginal persons in the community (Douglas, 1966; Turner, 1969; Perin, 1977: 110-15).

Local residents who denounced the assertion of personal injury claims and somewhat irrationally lamented the rise in "litigiousness" of personal injury plaintiffs were, in this sense, participating in a more broadly based ceremony of regret that the realities of contemporary American society could no longer be averted from their community if it were to survive. Their denunciations bore little relationship to the frequency with which personal injury lawsuits were actually filed, for the local ecology of conflict resolution still suppressed most such cases long before they got to court, and personal injury litigation remained rare and aberrational. Rather, the denunciation of personal injury litigation in Sander County was significant mainly as one aspect of a symbolic effort by members of the community to preserve a sense of meaning and coherence in the face of social changes that they found threatening and confusing. It was in this sense a solution-albeit a partial and unsatisfying one-to a problem basic to the human condition, the problem of living in a world that has lost the simplicity and innocence it is thought once to have had. The outcry against personal injury litigation was part of a broader effort by some residents of Sander County to exclude from their moral universe what they could not exclude from the physical 
boundaries of their community and to recall and reaffirm an untainted world that existed nowhere but in their imaginations.

\section{REFERENCES}

ABEL, Richard L. (1973) "A Comparative Theory of Dispute Institutions in Society," 8 Law \& Society Review 217.

AUBERT, Vilhelm (1963) "Competition and Dissensus: Two Types of Conflict and of Conflict Resolution," 7 Journal of Conflict Resolution 26.

BLACK, Donald (1976) The Behavior of Law. New York: Academic Press.

BLACK, Donald and M.P. BAUMGARTNER (1983) "Toward a Theory of the Third Party," in K. Boyum and L. Mather (eds.), Empirical Theories About Courts. New York: Longman.

DOUGLAS, Mary (1966) Purity and Danger. London: Routledge \& Kegan Paul, Limited.

ENGEL, David M. (1978) Code and Custom in a Thai Provincial Court. Tucson: University of Arizona Press.

- (1980) "Legal Pluralism in an American Community: Perspectives on a Civil Trial Court," 1980 American Bar Foundation Research Journal 425.

ERIKSON, Kai T. (1966) Wayward Puritans. New York: John Wiley \& Sons.

FELSTINER, William L.F. (1974) "Influences of Social Organization on Dispute Processing," 9 Law \& Society Review 63.

FRIEDMAN, Lawrence M. and Robert V. PERCIVAL (1976) "A Tale of Two Courts: Litigation in Alameda and San Benito Counties," 10 Law \& Society Review 267.

FULLER, Lon L. (1969) "Human Interaction and the Law," 14 American Journal of Jurisprudence 1.

GALANTER, Marc (1974) "Why the 'Haves' Come Out Ahead: Speculations on the Limits of Legal Change," 9 Law \& Society Review 95.

- (1983) "Reading the Landscape of Disputes: What We Know and Don't Know (And Think We Know) About Our Allegedly Contentious and Litigious Society," 31 UCLA Law Review 4.

GEST, Ted, Lucia SOLORZANO, Joseph P. SHAPIRO and Michael DOAN (1982) "See You in Court," 93 U.S. News \& World Report 58 (December 20).

GREENE, Richard (1983) "Caught in the Better Mousetrap," 132 Forbes 66 (October 24).

GREENHOUSE, Carol J. (1982) "Nature is to Culture as Praying is to Suing: Legal Pluralism in an American Suburb," 20 Journal of Legal Pluralism 17.

McINTOSH, Wayne (1980-81) "150 Years of Litigation and Dispute Settlement: A Court Tale," 15 Law \& Society Review 823.

NADER, Laura and Harry F. TODD, Jr. (1978) "Introduction: The Dispute Process-Law in Ten Societies," in L. Nader and H. Todd, Jr. (eds.), The Disputing Process-Law in Ten Societies. New York: Columbia University Press.

NATIONAL CENTER FOR STATE COURTS (1979) State Court Caseload Statistics: Annual Report, 1975.

(1982) State Court Caseload Statistics: Annual Report, 1977.

PERHAM, John (1977) "The Dilemma in Product Liability," 109 Dun's Review 48 (January).

PERIN, Constance (1977) Everything in Its Place. Princeton: Princeton University Press.

ROSENBERG, Maurice (1977) "Contemporary Litigation in the United States," in H. Jones (ed.), Legal Institutions Today: English and American Approaches Compared. Chicago: American Bar Association.

ROSS, H. Laurence (1970) Settled Out of Court. Chicago: Aldine Publishing Co.

SEYMOUR, Whitney North, Jr. (1973) Why Justice Fails. New York: William Morrow \& Co. 
SIMMEL, Georg (1908/1971) "The Stranger," in D. Levine (ed.), On Individuality and Social Forms: Selected Writings. Chicago: University of Chicago Press.

STEELE, Eric H. (1975) "Fraud, Dispute and the Consumer: Responding to Consumer Complaints," 123 University of Pennsylvania Law Review 1107.

TAYLOR, Stuart, Jr. (1981) "On the Evidence, Americans Would Rather Sue Than Settle," New York Times (July 5) Section 4, 8.

TODD, Harry F., Jr. (1978) "Litigious Marginals: Character and Disputing in a Bavarian Village," in L. Nader and H. Todd (eds.), The Disputing Process-Law in Ten Societies. New York: Columbia University Press.

TONDEL, Lyman M., Jr. (1976) "The Work of the American Bar Association Commission on Medical Professional Liability," 43 Insurance Counsel Journal 545.

TURNER, Victor W. (1969) The Ritual Process. Chicago: Aldine Publishing Co.

YAMAGUCHI, Masao (1977) "Kingship, Theatricality, and Marginal Reality in Japan," in R. Jain (ed.), Text and Context: The Social Anthropology of Tradition. Philadelphia: Institute for the Study of Human Issues.

YNGVESSON, Barbara and Patricia HENNESSEY (1975) "Small Claims, Complex Disputes: A Review of the Small Claims Literature," 9 Law \& Society Review 219. 